\title{
The old one technique in a new style: developing procedural skills in paracentesis in a low cost simulator model
}

\author{
Daniel Araujo Kramer de MESQUITA ${ }^{1}$, Erika Feitosa QUEIROZ ${ }^{1}$, Maria Allyce de OLIVEIRA', \\ Carlos Magno Queiroz da CUNHA $^{1}$, Fernanda Martins MAIA ${ }^{2}$ and Rafaela Vieira CORREA $^{3}$
}

Received 14/6/2018 Accepted 23/10/2018

\begin{abstract}
Background - Paracentesis is a routine medical procedure quite relevant in clinical practice. There are risks of complications related to paracentesis, so it is essential a proper trainee for the younger practicer. Objective - The article describes the construction and the application of a low cost paracentesis simulator for undergraduate medical students and it also describes the perception of students about the simulator as well. Methods - A low-cost model was developed by the Program of Tutorial Education for training medical students during three editions of an undergraduate theoretical-practical course of bedside invasive procedures. The authors constructed a model from very low-cost and easily accessible materials, such as commercial dummy plus wooden and plastic supports to represent the abdomen, synthetic leather fabric for the skin, upholstered sponge coated with plastic film to represent the abdominal wall and procedure gloves with water mixed with paint to simulate the ascitic fluid and other abdominal structures. One semi-structured form with quantitative and qualitative questions was applied for medical specialists and students in order to evaluate the paracentesis simulator. Results - The paracentesis model has an initial cost of US $\$ 22.00$ / R $\$ 70.00$ for 30 simulations and US $\$ 16.00$ / R $\$ 50.00$ for every 30 additional simulations. It was tested by eight medical doctors, including clinical medicine, general surgeons and gastroenterologists, and all of them fully agreed that the procedure should be performed on the manikin before in the actual patient, and they all approved the model for undergraduate education. A total of 87 undergraduate medical students ( $56 \%$ male) individually performed the procedure in our simulator. Regarding the steps of the procedure, $80.5 \%$ identified the appropriate place for needle puncture and $75.9 \%$ proceeded with the $\mathrm{Z}$ or traction technique. An amount of $80.5 \%$ of the students were able to aspire the fluid and another $80.5 \%$ of students correctly performed the bandage at the end of the procedure. All the students fully agreed that simulated paracentesis training should be performed prior to performing the procedure on a real patient. Conclusion-The elaboration of a teaching model in paracentesis provided unique experience to authors and participants, allowing a visible correlation of the human anatomy with synthetic materials, deepening knowledge of this basic science and developing creative skills, which enhances clinical practice. There are no data on the use of paracentesis simulation models in Brazilian universities. However, the procedure is quite accomplished in health services and needs to be trained. The model described above was presented as qualified with low cost and easily reproducible.
\end{abstract}

HEADINGS - Medical education. Simulation. Paracentesis.

\section{INTRODUCTION}

Paracentesis is a routine medical procedure and quite relevant in clinical practice, which consists of a needle puncture under local anesthesia of the abdominal cavity to collect ascitic fluid for therapeutic purpose or for laboratory diagnostic analysis. The accomplishment of this procedure is associated to lower mortality of hospitalized patients with ascites without a determined diagnosis, as well as the reduction of health $\operatorname{costs}^{(1,2)}$. However, like all invasive procedures, it presents complications, which can be minor ones $(9 \%)$ or large ones (approximately $1 \%$ ). In addition, a considerable percentage of complications $(6 \%)$ are related to problems with the technique used by the health professional ${ }^{(3)}$.

Due to its importance, high frequency in daily medical, and risk of complications, paracentesis training is essential in recognized medical curricula, such as The American Board of Internal
Medicine (ABIM) and the Accreditation Council for Graduate Medical Education ${ }^{(4)}$. In this context, the use of simulators to develop meaningful learning of procedural ability by undergraduate students proves to be effective. The great challenge is to make low-cost models, which present a good correlation with reality, to acquire the technique with repeated training ${ }^{(5-7)}$.

Thus, we demonstrate the construction and application of a simulated model of low cost paracentesis for the training of medical students in order to present an alternative way for teaching and training of the paracentesis technique.

\section{METHODS}

The first step of our study was the construction of four equal training models of paracentesis that were made in 2014, with the same characteristics of tested simulator in this study. The material 
for one model was a plastic mannequin, gloves filled with water, gummed tape, sponges and synthetic fabric leather. These materials were chosen due to easy access and handling, low-cost and reproducibility.

Using the plastic manikin as model patient, we made a circular incision on the whole abdominal from both costal borders and pelvic bones to simulate the abdominal cavity. We took out this part of model in such way that we proper filled the interior of the cavity with old newspapers in order to facilitate the attachment of a plastic compartment. The latter was filled with a geriatric diaper and the gloves.

Two gloves were positioned at the left iliac fossa of model and they had been previously filled with water to simulate the ascitic fluid which should be withdrawn from peritoneal cavity. Two other gloves had been filled with red and yellow liquid (colored by gouache paint) in order to simulate blood from abdominal vessels (red one) and enteric content (yellow one). These latter ones were proper positioned in the remaining space of the model cavity.

The disposal of the gloves in the model cavity had been chosen because our simulator could be able to allow the student perform a correct paracentesis with ascitic fluid (clear water) and a disaster paracentesis as well due to a visceral or vessel accidental punction.

The subcutaneous tissue was resembled by a $0.5 \mathrm{~cm}$ thick rectangular sponged used to cover the abdominal cavity. In the lower base of the sponge, in contact with the abdominal cavity, two layers of gummed tape were fixed, the first in the horizontal direction and the second in the perpendicular direction, representing the parietal peritoneum. These layers, when punctured with the needle, simulated a resistance as occurs in performing the real procedure. Lastly, the abdominal cavity was covered externally with the synthetic fabric leather tissue, to represent the skin (FIGURE 1).

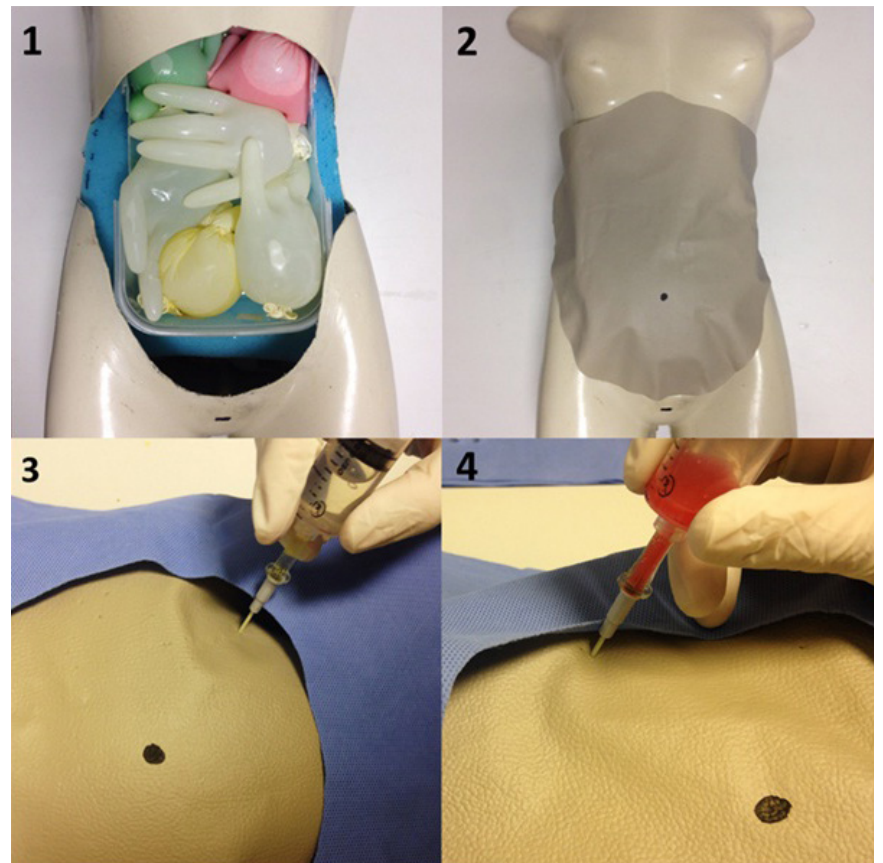

FIGURE 1. Simulator Model of Paracentesis: from different views. Materials from inside the manikin; 2. Manikin ready for use; 3 . Correct puncture view; 4 . Incorrect puncture view.
After the model was finalized, it was presented to medical specialists to train and approve the use of the teaching model. Thus, it was tested with eight physicians, who subsequently answered a questionnaire of semi-structured perception about quantitative and qualitative aspects of the model.

Primarily, the model was made to support the training with 10 students without needing to replace materials, especially the gloves. After that, the second step was the application of our model during three editions of an undergraduate theoretical-practical course of bedside invasive procedures during the period of 2015-2016.

This course was ministered by peer tutors previously trained in several procedures. The participants were instructed through a 10 minutes theoretical class, followed by a practical demonstration on the paracentesis simulated model, lasting around 10 minutes. Then, students performed the procedure individually, supervised by peer instructors. At this time, a checklist evaluation was used concerning procedure's performance. This checklist was elaborated by the researchers based on the literature ${ }^{(8,9,10)}$ (FIGURE 2).

\begin{tabular}{|c|c|c|c|}
\hline Stages of the procedure & Hit & Incomplete & Mistake \\
\hline $\begin{array}{l}\text { 1. Explained the procedure and obtained the } \\
\text { consent of the patient or legal guardian. }\end{array}$ & & & \\
\hline $\begin{array}{l}\text { 2. Has made sure that the bladder is empty } \\
\text { (request voiding, use a Foley or a relief tube). }\end{array}$ & & & \\
\hline $\begin{array}{l}\text { 3. Positioned the patient (horizontal dorsal } \\
\text { decubitus with discreetly elevated head). }\end{array}$ & & & \\
\hline $\begin{array}{l}\text { 4. Delimited the puncture site }(2 \mathrm{~cm} \text { below } \\
\text { the umbilical scar, in the midline or lower } \\
\text { quadrants, from the anterior-superior iliac } \\
\text { spine, measured } 2-4 \mathrm{~cm} \text { up and to the center } \\
\text { of the abdomen). }\end{array}$ & & & \\
\hline $\begin{array}{l}\text { 5. Confirmed the presence of fluid at the } \\
\text { puncture site with percussion. }\end{array}$ & & & \\
\hline 6. Performed local antisepsis. & & & \\
\hline 7. Positioned sterile field. & & & \\
\hline $\begin{array}{l}\text { 8. Performed local anesthesia with } 5 \mathrm{~mL} \text { of } \\
2 \% \text { lidocaine (anesthetic button }-1 \mathrm{~mL}+ \\
\text { deep tissue anesthesia }-4 \mathrm{~mL} \text { ). }\end{array}$ & & & \\
\hline $\begin{array}{l}\text { 9. Used a Z technique or needle insertion } \\
\text { with skin traction (the student aspired at } \\
\text { each advance of approximately } 3 \mathrm{~mm} \text { and } \\
\text { ceased when he/she aspirated ascitic fluid } \\
\text { or when he/she felt a sudden decrease in } \\
\text { resistance). }\end{array}$ & & & \\
\hline $\begin{array}{l}\text { 10. Student removed } 20-60 \mathrm{~mL} \text { of liquid } \\
\text { (he/she sent liquid for laboratory tests to } \\
\text { diagnose or connected the vial with vacuum } \\
\text { as a treatment). }\end{array}$ & & & \\
\hline 11. Removed the needle. & & & \\
\hline 12. Made sterile occlusive dressing. & & & \\
\hline $\begin{array}{l}\text { 13. Kept the patient under observation for } \\
\text { about } 60 \text { minutes. }\end{array}$ & & & \\
\hline
\end{tabular}

FIGURE 2. Checklist of paracentesis. 
The performance was considered satisfactory if a score greater than $70 \%$ was achieved. Each student took about 6 to 10 minutes to practice the procedure. After each training, the instructor provided individual feedback based on the checklist.

Focusing on evaluate the perception of the students about the model, a semi-structured questionnaire with quantitative and qualitative aspects was applied. The data collected were analyzed through the SPSS v. 22 using descriptive statistics.

The Kolmogorov Smirnov test was used to verify the normality of the sample. Values with $P<0.05$ were considered statistically significant.

This project was approved by the Research Ethics Committee of the University of Fortaleza under CAAE number: 30948814.2.0000.5052.

\section{RESULTS}

Low cost materials were used for the elaboration of the manikin (TABLE 1). This final formatting was the result of numerous tests with different materials, as exemplified below. Initially, a diaper was used to avoid wetting the simulator. Throughout the training, it was found that by filling one glove and covering it with two, the liquid did not overflow even after 30 repetitions of the technique. This change reduced costs with material replenishment, making the model even more reproducible at low cost.

TABLE 1. Materials of the Manikin.

\begin{tabular}{|c|c|c|}
\hline $\begin{array}{l}\text { Simulated } \\
\text { Structure }\end{array}$ & Material & Cost $(\mathrm{US} \$ / \mathrm{R} \$)$ \\
\hline Abdomen & $\begin{array}{l}\text { Commercial dummy plus } \\
\text { wooden and plastic supports }\end{array}$ & $6.00 / 19.00$ \\
\hline Skin & Synthetic leather fabric & $7.50 / 23.77 *$ \\
\hline Abdominal wall & $\begin{array}{l}\text { Upholstered sponge coated } \\
\text { with plastic film }\end{array}$ & $2.80 / 8.87 *$ \\
\hline $\begin{array}{l}\text { Ascitic fluid and } \\
\text { other structures } \\
\text { abdominal }\end{array}$ & $\begin{array}{l}\text { Procedure gloves with water } \\
\text { mixed with paint characteristic } \\
\text { of each structure }\end{array}$ & $5.40 / 17.11 *$ \\
\hline
\end{tabular}

*Cost for each 30 simulation.

It was also performed the inclusion of dyes to simulate different body fluids, allowing a greater similarity of the procedure to reality. To the simulator, gummed tape mass was added to the topography of the pubic symphysis to simulate this anatomical structure and serve as a reference point for the students.

Next, the model was tested and approved by eight professors from a university in Fortaleza, specialized in Gastroenterology (four), General Surgery (three) and Clinical Medicine (one). All reported having performed and assisted paracentesis in patients. The professionals answered a questionnaire of perception about the manikin, whose data are present in TABLE 2.

After the authors got the final version of the model, with a total cost of US\$22.00 / R \$70.00 initially for 30 simulations and US\$16.00 / R \$50.00 for each 30 further simulation, they used it in three editions of the course of bedside invasive procedures, when a total of 87 undergraduate medical students (56\% male) of varying ages and belonging to five distinct teaching institutions, individually
TABLE 2. Results of the professionals' perception questionnaire about the paracentesis model.

\begin{tabular}{lccccc}
\hline Question & TA & PA & IN & PD & TD \\
\hline $\begin{array}{l}\text { The model can be used for } \\
\text { undergraduate teaching }\end{array}$ & $100 \%$ & $0 \%$ & $0 \%$ & $0 \%$ & $0 \%$ \\
$\begin{array}{l}\text { Before performing paracentesis } \\
\text { in humans, mannequin training } \\
\text { is required }\end{array}$ & $100 \%$ & $0 \%$ & $0 \%$ & $0 \%$ & $0 \%$ \\
$\begin{array}{l}\text { The model is realistic } \\
\begin{array}{l}\text { The model is easy to reproduce } \\
\text { The }\end{array}\end{array}$ & $100 \%$ & $0 \%$ & $0 \%$ & $0 \%$ & $0 \%$ \\
\hline
\end{tabular}

Subtitle. Likert Scale. TA: I totally agree. PA: I partially agree. IN: indifferent. PD: partially disagree. TD: I totally disagree.

performed the procedure. Of these, $90.8 \%$ were in the first three years of medical school. The step-by-step of the checklist, as well as correctness and errors in performing the paracentesis procedure in the proposed simulator, is summarized in TABLE 3.

TABLE 3. Percentage of successful, incomplete or incorrect steps during the procedure.

\begin{tabular}{lcccc}
\hline Check list & Hit & Incomplete & Mistake & $P$ \\
\hline Selection of material & $33.3 \%$ & $6.9 \%$ & $59.8 \%$ & $<0.05$ \\
Positioning the patient & $32.2 \%$ & $20.7 \%$ & $47.1 \%$ & $<0.05$ \\
Asepsis and antisepsis & $63.2 \%$ & $31 \%$ & $5.8 \%$ & $<0.05$ \\
$\begin{array}{l}\text { Location of puncture } \\
\text { Anesthesia }\end{array}$ & $80.5 \%$ & $14.9 \%$ & $4.6 \%$ & $<0.05$ \\
$\begin{array}{l}\text { Puncture in Z technique } \\
\text { or traction }\end{array}$ & $75.9 \%$ & $16.1 \%$ & $8 \%$ & $<0.05$ \\
$\begin{array}{l}\text { Aspiration of ascitic } \\
\text { content }\end{array}$ & $80.5 \%$ & $14.9 \%$ & $4.6 \%$ & $<0.05$ \\
$\begin{array}{l}\text { Realization of the } \\
\text { dressing }\end{array}$ & $80.5 \%$ & $0 \%$ & $19.5 \%$ & $<0.05$ \\
\hline
\end{tabular}

The 87 answers to the perception questionnaire that was applied with students after the training revealed that $97.7 \%$ agree that it is an easy reproducible simulator and $100 \%$ agree that the simulator should be used for training before performing the paracentesis on real patients.

The model consists of an unprecedented production in the context of medical education, with no reports of use of similars models in the Brazilian literature, with the potential to develop the teaching of the procedure in a simple and accessible way.

\section{DISCUSSION}

It was seen that $50 \%$ of physicians fully agreed and another $50 \%$ partially agreed that the model was realistic and had good anatomical correlation. Those who agreed partially suggested in the qualitative part of the questionnaire that there should be a change in the model to better reproduce the physical examination 
that is performed before the procedure, putting more abdominal fluid into the cavity and leaving the abdominal wall more flexible, making it possible to reposition the umbilical scar according to the need and to hear the sounds of tympani and softness to the percussion of the abdomen.

Nevertheless, all the physicians who tested the model agreed that the model is easy to reproduce and that it can be used for undergraduate education, corroborating with data in the literature that says that to teach an efficient paracentesis, models must be updated and reproducible, and, above all, at an affordable cost, so that they can be used not only by universities, but also by extracurricular practical courses ${ }^{(11,12)}$.

Regarding the steps to perform the procedure, $59.8 \%$ of the students made an error when selecting the material, and only $32.2 \%$ correctly positioned the patient to start the abdominal fluid collection. Simple care such as checking equipment can make the difference between success and failure of a procedure. This simple conference can prevent the onset of various complications for the patients $^{(13)}$.

At the step of determining the localization for the puncture, $80.5 \%$ of the students identified the appropriate place and $75.9 \%$ proceeded with the $\mathrm{Z}$ technique or traction technique. Of the total, $60.9 \%$ had the concern of minimizing the patient's pain by using anesthesia. The risk of errors such as these can be reduced through standardization of behaviors and implementation of strict protocols, such as the safety checklist of the surgical procedure proposed by the World Health Organization ${ }^{(14)}$.

In the end, in one of the last stages of the procedure, $80.5 \%$ of the students were able to aspire the ascitic fluid to send for analysis, with $80.5 \%$ performing the bandage to finish the procedure.

In agreement with the proposal of the authors, the result of an international multicenter evaluation showed that the use of checklist almost doubled the chance of patients receiving surgical treatment with adequate standards of care, reducing morbidity and mortality ${ }^{(14)}$.

It was interesting to notice that most of the students and all professionals fully agreed that simulated paracentesis training should be performed prior to performing the procedure on a real patient. This is in agreement with many studies that state that the practice in synthetic models is efficient for the learning process, for the acquisition of skills and for students to gain confidence, in comparison to teaching based only on the observation of physi- cians performing the procedures ${ }^{(15,16)}$. As a consequence, training in simulated mannequins, such as paracentesis, contributes to improve safety in performing this important procedure in the real patient $^{(10,14)}$.

In this way, our model is reproducible in undergraduate students and professionals opinion, as seen in the results of the perception questionnaire, corroborating the hypothesis that the model can be used for large-scale teaching in other courses or within the medical curriculum itself to improve students confidence and learning of paracentesis.

Furthermore, it is important to highlight that commercial models for simulation of the paracentesis procedure vary the cost between US\$1000-2000 / R \$3000-6000. These models require logistical planning for storage and transportation in different sectors of the institution.

Also, the lack of a model in the country that brings all these benefits reinforces the relevance of propagating the use of this simulator, expanding the studies in other schools.

\section{CONCLUSION}

It was observed that, with low-cost and easily accessible materials, it was possible to create a paracentesis training model for undergraduate students, being well evaluated by the study population. We highlight the significant anatomy learning that the construction and visualization of the finalized model provided to authors and participants.

There are no data on the use of paracentesis simulation models in Brazilian universities. However, the procedure is performed in the health services and needs to be trained. Further studies are needed to demonstrate the efficacy of this method, with more varied samples and more experienced professionals to test the model.

\section{Authors' contribution}

Mesquita DAK: collection of the data, literature review, data interpretation and text translation. Queiroz EF: structuring methodology, data interpretation and text translation. Oliveira MA: collection of the data, checked the results, data interpretation and text translation. Cunha CMQ: quality control and statistical analyses and data interpretation. Maia FM and Correa RV were the chiefs investigators and revised the data and critically revised the manuscript. All authors revised and approved the final report. 
Mesquita DAK, Queiroz EF, Oliveira MA, Cunha CMQ, Maia FM, Correa RV. A antiga técnica em um novo estilo: desenvolvendo habilidades procedimentais em paracentese em simulador de baixo custo. Arq Gastroenterol. 2018;55(4):375-9.

RESUMO - Contexto - A paracentese é um procedimento médico de rotina bastante relevante na prática clínica. Devido à sua importância na assistência médica diária e seus riscos de complicações, o treino do procedimento é essencial em currículos médicos reconhecidos. Objetivo - Descrever a construção de um simulador de paracentese de baixo custo, destacando a percepção de estudantes sobre o seu uso para treinamento na graduação em Medicina. Métodos - Um modelo de baixo custo foi desenvolvido pelo Programa de Educação Tutorial para treinamento de estudantes de Medicina durante três edições de um curso teórico-prático de procedimentos invasivos à beira do leito. Os autores construíram um modelo a partir de materiais comuns e de fácil acesso, como manequim comercial e suportes de madeira e plástico para representar o abdômen, tecido de couro sintético para a pele, esponja revestida com filme plástico para representar a parede abdominal e luvas de procedimento com água misturada com tinta para simular o líquido ascítico e outras estruturas abdominais. Para avaliar o modelo, aplicou-se um questionário semiestruturado com aspectos quantitativos e qualitativos para médicos especialistas e estudantes. Resultados - O modelo para paracentese tem orçamento inicial de US $\$ 22.00$ / R $\$ 70,00$ para 30 simulações e US\$16.00 / R\$50,00 para cada 30 simulações adicionais. Foi testado por oito especialistas (clínico geral, cirurgião geral e gastroenterologista), dos quais quatro são gastroenterologistas, e todos concordaram plenamente que o procedimento deve ser realizado no manequim antes de ser feito no paciente real, e todos eles aprovaram o modelo para o ensino de graduação. Durante as edições do curso, um total de 87 estudantes de graduação em Medicina ( $56 \%$ homens) realizaram individualmente o procedimento. Em relação às etapas do procedimento, do total de alunos avaliados, $80,5 \%$ identificaram o local apropriado para a punção e $75,9 \%$ procederam com a técnica $\mathrm{Z}$ ou tração. Ao final, $80,5 \%$ dos alunos conseguiram aspirar ao conteúdo ascítico, com $80,5 \%$ realizando o curativo e finalizando o procedimento. Todos os alunos concordaram plenamente que o treinamento com paracentese simulada deve ser feito antes de se realizar o procedimento em um paciente real. Conclusão - A elaboração de um modelo de ensino em paracentese proporcionou experiência única a autores e participantes, permitindo uma visível correlação da anatomia humana com materiais sintéticos, aprofundando o conhecimento desta ciência básica e desenvolvendo habilidades criativas, o que potencializa a prática clínica. Não há dados sobre o uso de modelos de simulação de paracentese em universidades brasileiras. No entanto, o procedimento é bastante realizado nos serviços de saúde e precisa ser treinado. O modelo descrito acima foi apresentado como de qualidade, baixo custo e de fácil reprodutibilidade, sendo inédito no cenário da educação médica nacional, mostrando-se uma ferramenta complementar de ensino na graduação e preparando os alunos para o procedimento in vivo.

DESCRITORES - Educação médica. Simulação. Paracentese.

\section{REFERENCES}

1. Orman ES, Hayashi PH, Bataller R, Barritt AS. Paracentesis is associated with reduced mortality in patients hospitalized with cirrhosis and ascites. Clin Gastroenterol Hepatol. 2014;12:496-503.

2. Barsuk JH, Feinglass J, Kozmic SE, Hohmann SF, Ganger D, Wayne DB. Specialties performing paracentesis procedures at university hospitals: implications for training and certification. J Hosp Med. 2014;9:162-8.

3. Wiese SS, Mortensen C, Bendtsen F. Few complications after paracentesis in patients with cirrhosis and refractory ascites. Dan Med Bul. 2011;58:A4212.

4. Barsuk J, Cohen E, Vozenilek J, O’Connor L, McGaghie W, Wayne D. Simulation-Based Education with Mastery Learning Improves Paracentesis Skills. J Grad Med Educ. 2012;4:23-27.

5. Graafland M, Schraagen J, Schijven M. Systematic review of serious games for medical education and surgical skills training. Br J Surg. 2012;99:1322-30.

6. Fouilloux V, Gsell T, Lebel S, Kreitmann B, Berdah S. Assessment of team training in management of adverse acute events occurring during cardiopulmonary bypass procedure: a pilot study based on an animal simulation model (Fouilloux, Team training in cardiac surgery). Perfusion. 2014;29:44-52.

7. Ziv A, Ben-David S, Ziv M. Simulation Based Medical Education: an opportunity to learn from errors. Med Teach. 2005;27:193-99.

8. Riesenberg LA, Berg K, Berg D, Mealey K, Weber D, King D, Justice EM, Geffe K, Tinkoff G. Development of a Validated Checklist for Paracentesis: Preliminary Results. Am J Med Qual. 2013;28:227-31.
9. Aragão LC, Andrade HBS, Menezes FJC. Paracentese. In: Menezes FJC, Morano JACOD, Cunha CMQ. Habilidades Cirúrgicas Essenciais. $1^{\mathrm{a}}$ edição. Fortaleza: Universidade de Fortaleza; 2017. p. 96-99.

10. Melo MCB, Magalhães AMPB, Silva NLC, Liu PMF, Cerqueira LC, Gresta $\mathrm{MM}$, et al. Simulation based on learning and communication skills techniques in health area. Rev Med Minas Gerais. 2016;26:1805.

11. Cheng A, Lockey A, Bhanji F, Lin Y, Hunt E, Lang E. The use of high-fidelity manikins for advanced life support training - A systematic review and meta-analysis. Resuscitation. 2015;93:142-9.

12. Issenberg SB, Scalese RJ. Five Tips for a Successful Submission on Simulation-Based Medical Education. J Grad Med Educ. 2014;6:623-5.

13. Pancieri AP, Santos BP, Avila MAG, Braga EM. Checklist de cirurgia segura: análise da segurança e comunicação das equipes de um hospital escola. Rev Gaúcha Enferm. 2013;34:71-8.

14. Organização Mundial de Saúde. Orientações da OMS para a Cirurgia Segura 2009 Cirurgia Segura Salva Vidas. Diretor-Geral da Saúde; 2009.

15. Lynagh M, Burton R, Sanson-Fisher R. A systematic review of medical skills laboratory training: where to from here? Med Educ. 2007;41:879-87.

16. Khan K, Pattison T, Sherwood M. Simulation in medical education. Med Teach. 2010;33:1-3. 